\title{
Comprehending Determinants of Demand: Zimbabwe Tourism Destination Scenario
}

\author{
Farai Chigora \\ Graduate School of Business and Leadership \\ Westville Campus, University of KwaZulu-Natal, South Africa and Catholic University of \\ Zimbabwe \\ PO Box H200, Hatfield, Harare, Zimbabwe \\ Tel: 263-772-886-871_E-mail: fchigora@yahoo.com (corresponding Email)
}

\author{
Clever Vutete \\ Zimbabwe Open University-Harare Region \\ Tel: 263-772-458-026Ｅ-mail: vusabhuku@gmail.com
}

Received: August 24, 2015 Accepted: October 13, 2015 Published: December 7, 2015

doi:10.5296/ieb.v1i2.8689

URL: http://dx.doi.org/10.5296/ieb.v1i2.8689

\begin{abstract}
The study investigated on the most dominant determinants of tourism consumption in Zimbabwe tourism destination. The research design was a QUAL to QUAN sequential mixed method starting with a qualitative research design followed by quantitative research. The qualitative research helped in getting the main determinants of demand using in-depth interviews from managers and experts in the tourism industry. The agreed determinants include disposable income, demographic changes, change in taste and preferences, religion dynamics, globalization, marketing and advertisement, customer knowledge, destination branding, social networks, destination's own price, price of other destinations and media propaganda. These where then tested for their dominance in the accommodation, travel and resort sectors in Zimbabwe through a quantitative design. The results showed that the most controlling determinants of tourism demand in these three sectors include destination's own prices, level of disposable income, social network discussions, media propaganda, marketing and advertising. The study recommended a low pricing strategy, extensive marketing and utilization of e-resources in marketing.
\end{abstract}

Keywords: Determinants of demand, Zimbabwe, Tourism destination 


\section{1) Macrothink}

\section{Introduction}

According to World Bank (2006) tourism has been regarded as an important sector that helps in promoting economic growth and alleviating poverty. Zimbabwe has various natural and man-made resources including one of the world's wonders the majestic Victoria Falls, one of the largest man-made dams (Kariba Dam) and various eco-diversity (Muchapondwa \& Pimhidzai, 2011).

The concept of tourism demand has been derived from the classical definition of demand which is the willingness and ability to consume a product or service at a given price and period in time (Song, Li, Witt, \& Fei, 2010). Zimbabwe tourism industry has faced a decline in tourists arrivals over the years mainly attributed to negative changes in the socio-economic and political issues (Ndlovu \& Heath, 2013). Both local and international tourists have reduced their willingness and ability to consume tourism in Zimbabwe. As with the demand of general products, international tourism is affected by both negative and positive shocks and political risk can be noted as one of the important determinants of international tourism (Muchapondwa \& Pimhidzai, 2011).

Figure 1 below shows the performance of Zimbabwe tourism industry on the international market between year 1994 and 2005. The trend shows that from 1994 to 1999 there was an increase in the tourists' arrivals. In the year 2000 there was a major slump in the arrivals and again between year 2003 and 2005 such trends continued into the current years. In terms of growth as shown in Figure 1 the country has faced a negative trend from year 1995 whilst the trend has been a bit stable for Africa as a continent.

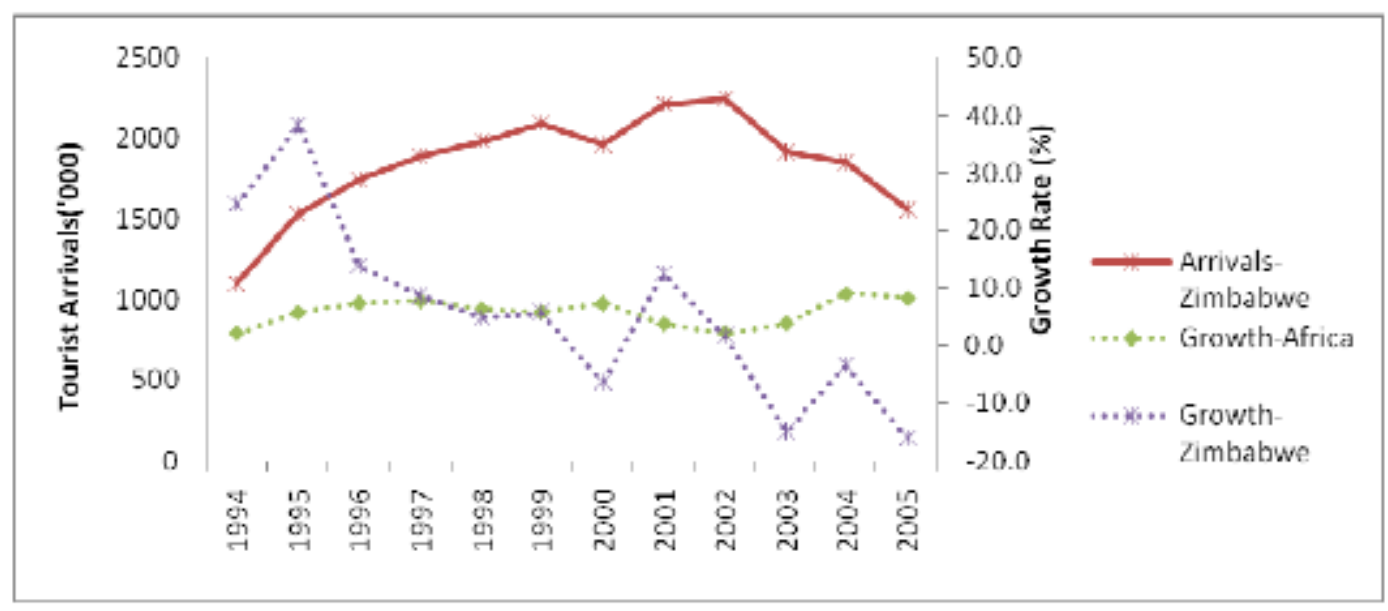

Figure 1. Performance of international tourism in Zimbabwe

Source: Source: UNWTO (2006).

The main reasons for the poor performance of the Zimbabwe tourism industry have been attributed to events shown in Figure 2 below. 


\section{MInstitute Macrink $_{\text {Inth }}$}

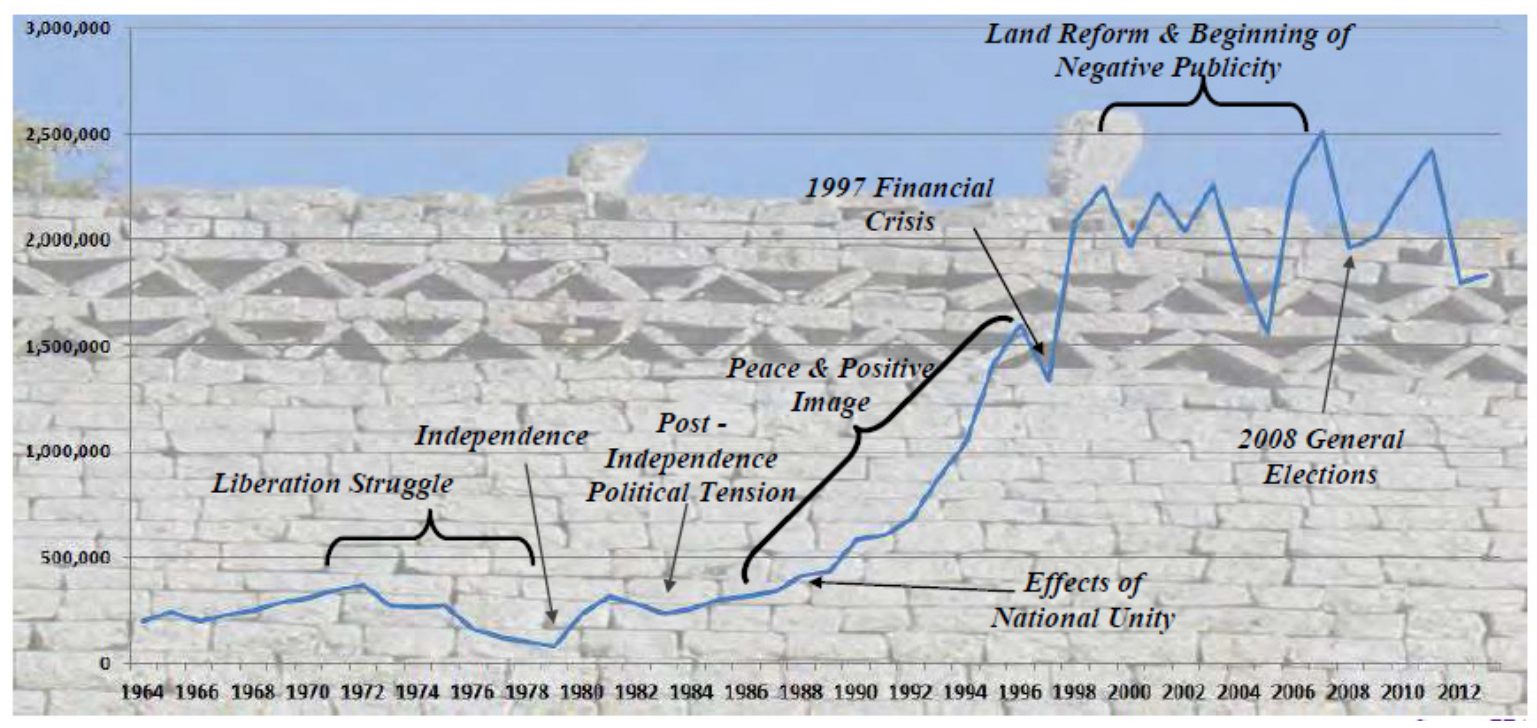

Figure 2. Events that affected Zimbabwe tourism

Source: Zimbabwe Tourism Authority (2013).

As shown in figure 1.2 above, after the country's independence in 1980 there was an increase in tourists' arrivals though with some minor decreases caused by post independence political tensions. In 2000 the country faced a downfall in the arrivals due to the land reform program that was not appreciated by the former colonies who dominated the traditional western tourism market. In 2008 the general elections associated with violence resulted in another downfall. However, these events have been pointed as the main contributors to the falling tourism industry in Zimbabwe but there are no well established determinants of demand for the Zimbabwe tourism destination. The study therefore investigated on the most dominant determinants of tourism demand in Zimbabwe.

\subsection{Statement of Problem}

The demand for the tourism products and services is falling in Zimbabwe. This has affected the growth of the industry which is one of the key economic drivers in the country. The study therefore, investigated on the key tourism demand determinants in Zimbabwe. This was with an aim to know the most favourable determinants which tourism authorities should invest on their promotional strategies so as to stimulate sustainable demand.

\section{Literature Review}

In the past research on international tourism demand has been associated with developed countries with a few looking at Africa's tourism demand (Rogerson, 2007). Demand is the ability and willingness to consume a product or service at a given price and period in time. The tourism demand has been labeled as special comprising of a bundle of complementary goods and services (Morley, 1992). Price is the main determinant of demand (Lipsey, 2009). Price helps in understanding the law that governs demand which says that there is an inverse relationship between price and quantity demanded (Samuelson \& Nordhaus, 2005). This 
means that more quantity is demanded at a lower price than at a higher price. The relationship between price and quantity demanded is shown in Figure 3 below.

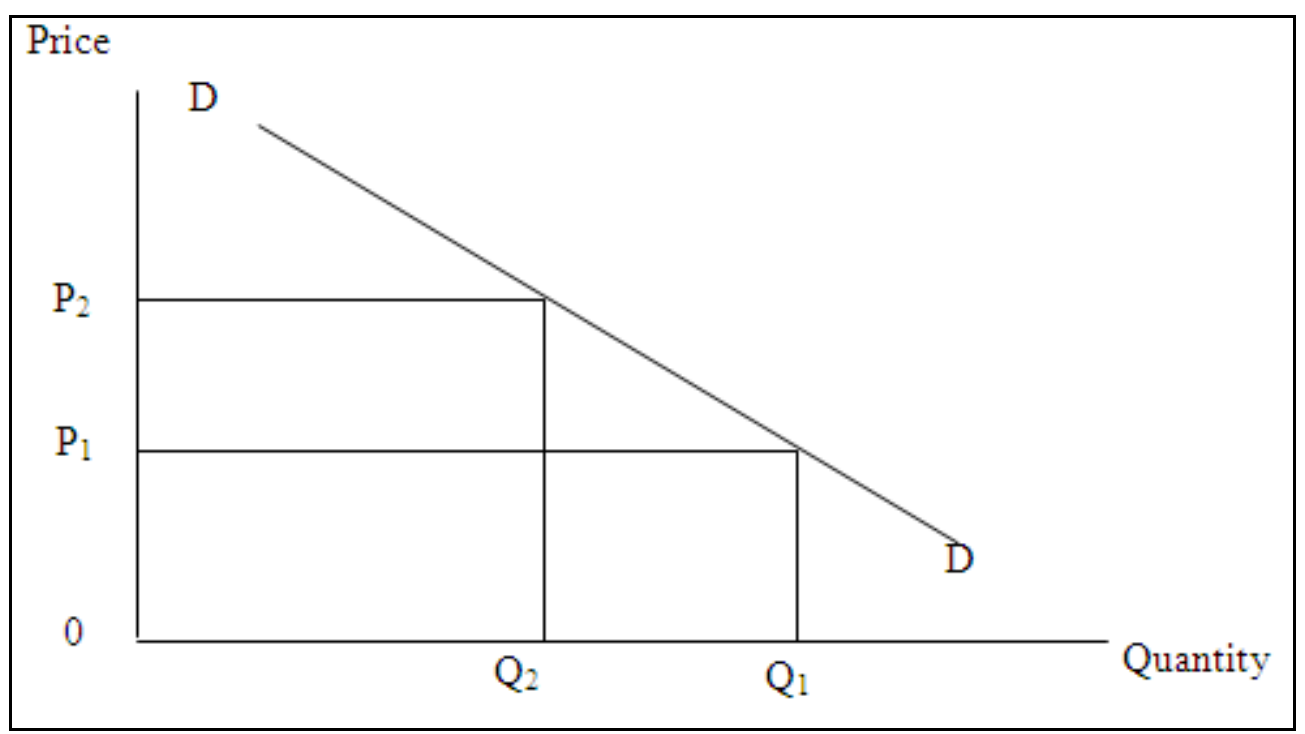

Figure 3. Demand Curve

Source: Research Design (2015).

As shown in Figure 3 above, at a higher price $\mathrm{P}_{2}$ a lower quantity of $\mathrm{Q}_{2}$ is demanded as compared to a lower price $\mathrm{P}_{1}$ where more quantity $\mathrm{Q}_{1}$ is demanded. There are also other determinants of demand beside price. These cause a total shift in the current demand. The determinants include disposable income, advertising, changes in taste and preferences and price of other related goods and services. In diversified models price for tourism, taste formation and income from country of origin have formed the most critical determinants of international tourism demand (Muchapondwa \& Pimhidzai, 2011). Various studies have researched on with the aim to include promotion or advertising in the analysis of tourism (Divisekera and Kulendran, 2006). It is easy to understand the determinants of tourism demand from a local perspective than at an international level (Muchapondwa \& Pimhidzai, 2011).

\section{Methodology}

A qualitative to quantitative sequential mixed method was used as a research design for the study. The qualitative data was obtained through in-depth interviews as research instruments from 10 senior economists who informed on the key determinants of demand in Zimbabwe tourism industry. The determinants were analysed on their dominance in three main tourism sectors using survey questionnaires as quantitative research instruments. The respondents were therefore 35 from accommodation sector, 25 from travel sector and 15 from resorts making the entire population 75 respondents. Data analysis was done using average means from 1 to 5 ( $1=$ Strongly Agree, 5= Strongly Disagree). 


\subsection{Findings and Discussions}

The research applied a qualitative approach to establish the major determinants for tourism demand in Zimbabwe. This was through in-depth interviews with 10 government economists. These determinants were then analysed to find out the most dominant ones in Zimbabwe tourism destination using survey questionnaires as quantitative research instruments. The results are therefore presented in Table 1 and Figure 4 below.

The average mean statistics in Table 1 and Figure 4 shows that social networking is the most dominant determinant of tourism demand in Zimbabwe. This is represented by its lowest average mean of 1.045. This is followed by marketing and advertising with an average mean of 1.129 and destination branding with 1.242. These factors with low average means are mainly to do with destination information management. Social media has been used to exchange information from and amongst tourists, between tourists and tourism businesses. The platforms affect attitudinal behaviour through reference and word of mouth. This means that when negative information is spread, there will be a reduction in the demand for tourism products and offerings. Also failure to advertise and market a destination will reduce its chances to be known globally hence affecting the demand negatively. Destination branding has become an effective tool to position and improve identity of destinations. This has helped in building positive image, create awareness, improve perceived quality and loyalty thus strengthening aggregate demand.

Table 1. Responses on the determinants of tourism demand in Zimbabwe

\begin{tabular}{|l|c|c|c|c|c|}
\hline Determinants of demand & $\begin{array}{c}\text { Accommodation } \\
\text { sector }\end{array}$ & $\begin{array}{c}\text { Travel } \\
\text { sector }\end{array}$ & $\begin{array}{c}\text { Tourism } \\
\text { resorts }\end{array}$ & $\begin{array}{c}\text { Total } \\
\text { means }\end{array}$ & $\begin{array}{c}\text { Average } \\
\text { means }\end{array}$ \\
\hline Disposable income & 1.101 & 1.211 & 1.789 & 4.101 & 1.367 \\
\hline Price charges & 1.945 & 1.917 & 1.898 & 5.760 & 1.920 \\
\hline Demographic changes & 2.156 & 2.529 & 1.763 & 6.448 & 2.149 \\
\hline $\begin{array}{l}\text { Changes in taste and } \\
\text { preferences }\end{array}$ & 1.875 & 1.238 & 2.988 & 6.101 & 2.033 \\
\hline Religion dynamics & 2.134 & 2.792 & 1.912 & 6.838 & 2.279 \\
\hline Globalisation & 2.051 & 2.799 & 2.170 & 7.020 & 2.340 \\
\hline $\begin{array}{l}\text { Marketing and } \\
\text { advertisement }\end{array}$ & 1.023 & 1.336 & 1.029 & 3.388 & 1.129 \\
\hline Customer knowledge & 1.985 & 2.033 & 3.01 & 7.028 & 2.343 \\
\hline Destination branding & 1.213 & 1.511 & 1.001 & 3.725 & 1.242 \\
\hline Social network & 1.001 & 1.102 & 1.032 & 3.135 & 1.045 \\
\hline Price of other destinations & 1.989 & 2.018 & 1.913 & 5.920 & 1.973 \\
\hline Media propaganda & 1.662 & 1.213 & 1.015 & 3.890 & 1.297 \\
\hline
\end{tabular}

Note. The average mean are in a range of 1-5 (1= Strongly Agree; $5=$ Strongly Disagree).

Source: Research Survey (2015). 


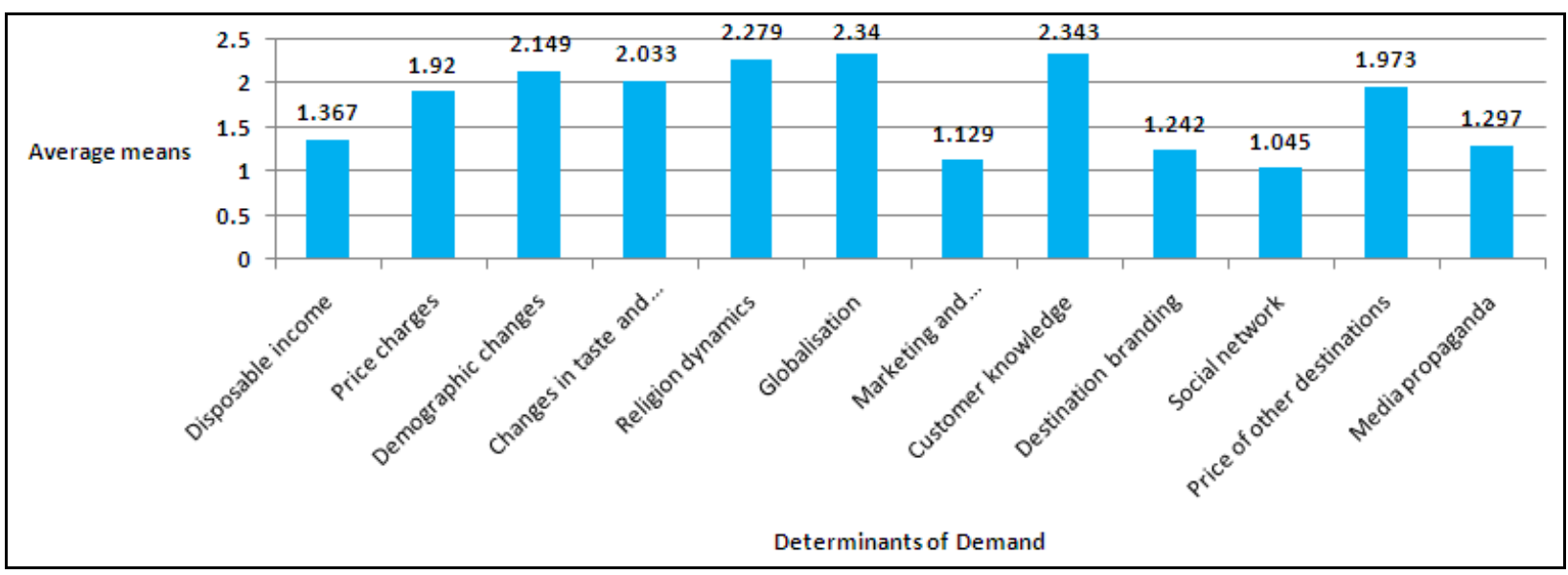

Figure 4. Responses on the determinants of tourism demand in Zimbabwe

Note. The average mean are in a range of 1-5 (1= Strongly Agree; $5=$ Strongly Disagree $)$.

Source: Research Survey (2015).

\section{Conclusions}

The study shows that there are several issues that have affected the demand for the tourism products in Zimbabwe. The main determinants controlling the ability and willingness to consume in the Zimbabwe tourism destination include prices of tourism offerings, level of disposable income, social network discussions, media propaganda, marketing and advertising. These are critical issues as they affect the psychological state of the tourist which triggers the desire to or not to consume. Tourism destination managers should therefore strive to align with these determinants in order to stimulate demand.

\section{Recommendations}

The tourism destination operators in Zimbabwe should find ways of reducing their operational costs so that they charge reasonable and affordable prices in relation to low levels of disposable income of the potential tourists. These include mergers, joint ventures, recycling and waste management, use of natural resources and other sustainable practice measures. The practices help in reducing costs through achieving economies of scale and using free nature provided resources.

There is need to improve in marketing and advertising of the tourism offerings in Zimbabwe destination. The research revealed that some of the local residents do not even know the most attractive places in their country. This is attributed to low levels of marketing and advertising. The destination will not be able to stimulate demand of foreign more than it can manipulate the demand for locals.

E-resource marketing using social media platforms can help in improving demand for the tourism offerings both locally and internationally. This is because social media has taken precedence in promoting attitudinal brand loyalty of the tourists through word of mouth and 
experience discussions on social platforms. There is a need to therefore conform the bandwagon so as to win the hearts and minds of the tourists by convincing them to engage and buy in. This can also be related to media propaganda which has spread negative vitriol about Zimbabwe tourism destination. Destination authorities should ensure they defend themselves from the most common media that has informed negativity about the country's tourism destination offerings.

\section{References}

Divisekera, S., \& Kulendran, N. (2006). Economic effects of advertising on tourism demand: A case study. Tourism Economics, 12(2), 187-205.

Lipsey, R. G. (2009). An Introduction to Positive Economics (7th ed.). Oxford University Press: Oxford.

Morley, C. (1992). A microeconomic theory of international tourism demand. Annals of Tourism Research, 19, 250-267.

Muchapondwa, E., \& Pimhidzai, O. (2011). Modelling International Tourism Demand for Zimbabwe. International Journal of Business and Social Science, 2(2), 71-81.

Ndlovu, J., \& Heath, E. (2013). Re-branding of Zimbabwe to enhance sustainable tourism development: Panacea or Villain. Academic Journals, 1(12), 947-955.

Rogerson, C. M. (2007). Reviewing Africa in the global tourism economy. Development Southern Africa, 24(3), 361-379.

Samuelson, P. A., \& Nordhaus, W. D. (2005). Economics (18th ed.). McGraw-Hill: New Delhi.

Song, H., Li, G., Witt, S. F., \& Fei, B. (2010). Tourism demand modelling and forecasting: How should demand be measured? Tourism Economics, 16(1), 63-81.

United Nations World Tourism Organisation (UNWTO). (2006). Tourism Trends (2005 ed.). UNWTO: New York.

World Bank. (2006). Ethiopia: Towards a strategy for pro-poor tourism. Africa Private Sector Development Note 24. World Bank: Washington DC.

Zimbabwe Tourism Authority. (2013). Annual Report.

\section{Copyright Disclaimer}

Copyright for this article is retained by the author(s), with first publication rights granted to the journal. This is an open-access article distributed under the terms and conditions of the Creative Commons Attribution license (http://creativecommons.org/licenses/by/3.0/). 